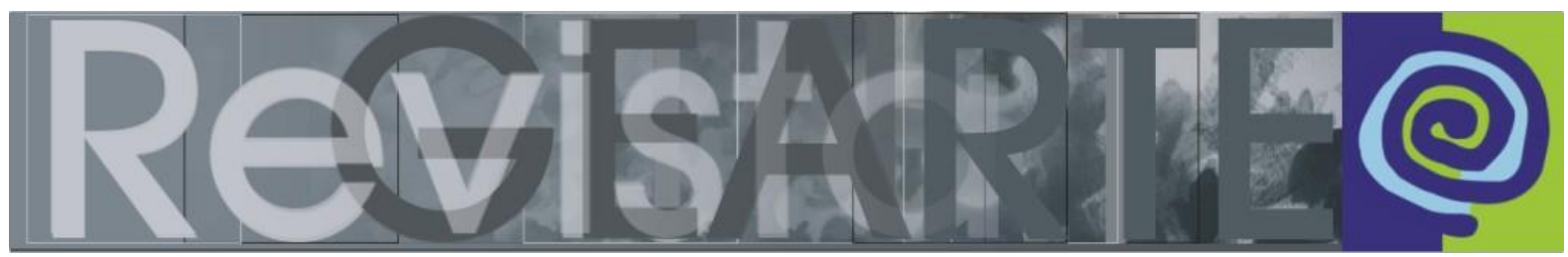

e-ISSN 2357-9854

\title{
Cérebros criativos no mundo das produções audiovisuais de massa? Entretenimento, fãs de animações e possibilidades criativas em artes visuais
}

\author{
Isac dos Santos Pereira \\ (Universidade Anhembi Morumbi — UAM, São Paulo/SP, Brasil)
}

\begin{abstract}
RESUMO - Cérebros criativos no mundo das produções audiovisuais de massa? Entretenimento, fãs de animações e possibilidades criativas em artes visuais - A presente pesquisa surgiu da inquietação suscitada a partir da reflexão sobre até que ponto a comunicação audiovisual, especificamente as animações televisivas, e seus hiperestímulos deixam de ser mero entretenimento dentro do complexo contemporâneo para de fato serem úteis para os estudos da criatividade, além de subsidiar no processo criativo de seus fãs. A assimilação de tais constructos carece da atuação de diversos campos sensoriais, que retém e encaminham as informações às diversas vias cerebrais. Em diálogo com o pensamento complexo de Edgard Morin, o texto se funda na intenção de entender algumas das faces das animações infanto-juvenis enquanto arcabouço complexo, que se instaura e afeta diversos campos do imaginário e, tão logo propicia o ato criador ao propor novas animações, como o caso de alguns produtores. Doravante, os olhares investigativos lançaram-se aos escritos partindo de uma concepção positiva sobre os meios audiovisuais, visando discutir sobre algumas produções e, sua consequente influência na conformação do arcabouço imagético das crianças/fãs que as consomem constantemente nos momentos de lazer, os agregam e externalizam suas percepções por meio de desenhos dentro da sala de aula.
\end{abstract}

PALAVRAS-CHAVE

Televisão. Animação. Processo criativo. Estímulo cerebral. Arte. Desenho.

ABSTRACT - Creative brains in the world of mass audiovisual productions? Entertainment, fans of animations and creative possibilities in the visual arts - The present research arose from the restlessness arising from the reflection on the extent to which the audiovisual communication, specifically the television animations, and their hyperstimuli, are no longer mere entertainment within the contemporary complex to fact to be useful for the studies of creativity, besides subsidizing in the creative process of its fans. The assimilation of such constructs lacks the actuation of several sensorial fields, which retains and directs information to the various cerebral pathways. In dialogue with the complex thinking of Edgard Morin, the text is based on the intention of understanding some of the faces of infantile-juvenile animations as a complex framework that establishes and affects diverse fields of the imaginary and, as soon as it fosters the creative act in proposing new such as the case of some producers. From now on, the investigative looks have been written with a positive conception of the audiovisual media, aiming at discussing some productions and their consequent influence on the conformation of the image-frame of the children / fans who constantly consume them in the moments of leisure, and externalize their perceptions through drawings within the classroom.

\section{KEYWORDS}

Television. Animation. Creative process. Stimulus of the brain. Art. Drawing.

\section{Para início de conversa}

No galgar da sociedade do século $X X$ para o $X X I$, todos os meios de comunicação, especificamente as produções televisivas, exacerbaram-se de modo 


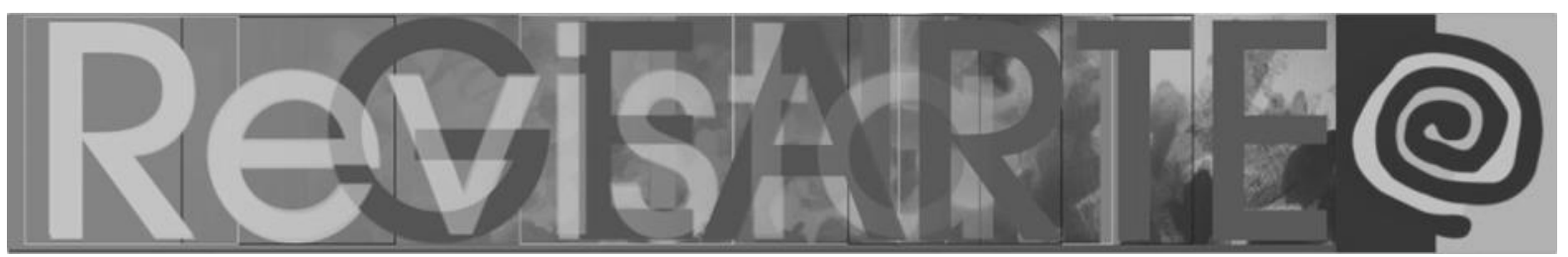

quase que imensurável. Em paralelo, muito se ouve sobre críticas que irrompem de forma constante a essas produções contemporâneas, problematizando-as como objetos que tem por finalidade única o entretenimento ou a manipulação das massas através de seus hiperestímulos visuais e sonoros. Diante das inquietações e das profusões de mudanças que brotam entre o início da modernidade e se estende à contemporaneidade, encontram-se diversos teóricos que de um determinado ponto de vista contemplam o complexo social e midiático e o tomam como objeto de reflexão e problematização. Imersos nessas ações conjecturais, nos deparamos com teóricos como Adorno e Horkheimer (1985, p.58), que ao dialogarem sobre as mudanças que se delineiam dentro do arcabouço da indústria cultural, e tão logo as produções midiáticas, crêem que as produções televisivas ao desejarem uma "síntese do rádio e do cinema" com possibilidades limitadas, "prometem aumentar o empobrecimento dos materiais estéticos", dando fim à harmonia musical, as particularidades pictóricas e as interlocuções entre o ser psicológico no romance.

Todavia, ressalta-se que a forma aqui tomada para salientar os hiperestímulos advindos do contato que o ser humano tem às produções audiovisuais massivas contemporâneas, vai de encontro com as preconizações e elucubrações supracitadas juntamente, doravante, com as de Singer (2001, p.116) que, em delongas textuais defendera a ideia de uma sociedade conformada por um volume crítico, imbuído de "choques físicos e perceptivos do ambiente urbano (...) marcadamente mais rápido, caótico, fragmentado e desorientador do que as fases anteriores da cultura humana", configurando uma rede de imprensa midiática sensacionalista diante dos achados negativos que tal profusão se deu. Nem é crido também que as produções, como as cinematográficas, são treinamentos "em lidar com os estímulos do mundo moderno", como supôs Walter Benjamin (apud SINGER, 2001, p.141). Seria um erro se apegar a tantos pensamentos depreciativos e negativos sobre a comunicação audiovisual de massa em meio aos conjuntos de experiências qualitativas existentes.

De fato, há campos que se utilizam de tais meios para a degradação da ação humana e o total desvio de suas reais funções dentro do âmbito social. Contudo 


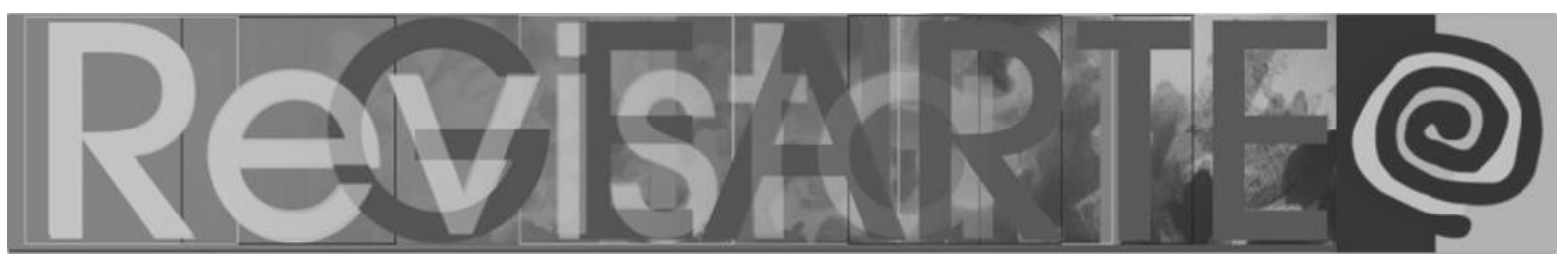

produzem-se também constructos que dialogam com o pensamento reflexivo dos consumidores, inserem conhecimentos e fazem com que irrompam ações deveras plausíveis para os atores contemporâneos da sociedade. A pesquisa é balizada pela menção positiva às produções para a TV, processos de criação de alguns produtores de animação, investigações textuais e artísticas (desenhos infanto-juvenis), salientando a qualidade e necessidade de tal interlocução como uma das premissas a ser avaliada e refletida em tempos de profusões midiáticas. Os escritos deter-se-ão às concepções díspares, a defender à luz de conhecimentos neurocientíficos e da comunicação, os vieses positivos que tal consumo consciente pode corroborar, como por exemplo, o ato criador. Anseiam por refletir algumas animações coetâneas passadas na televisão, mais detidamente às crianças, fazendo com "que toda percepção seja uma tradução reconstrutora realizada pelo cérebro, a partir de terminais sensoriais, e que nenhum conhecimento possa dispensar interpretação" (MORIN, 2001, p.52) e ser deixado de lado, sem seu devido valor.

No arcabouço reflexivo das pesquisas existem diversas abordagens que discorrem de forma dispendiosa sobre $o$ ato criativo, desde concepções psicodélicas até humanistas, biológicas, filosóficas e psicoeducacionais; entretanto os estudos se direcionarão brevemente ao entendimento dentro dos constructos textuais de pesquisas neuropsicológicas, que buscam sanar dúvidas suscitadas em diversos contextos sociais.

Adiante, o texto se segue e finaliza com uma proposta de investigação de campo dentro do sistema público da prefeitura do município de São Paulo, congregando alguns desenhos de crianças que consomem diariamente produções televisivas e fazem novas combinações criativamente ao desenvolverem as propostas de diversas disciplinas. Com isso, o texto faz uma interlocução entre seu ato criativo com o de grandes produtores de animações infanto-juvenis, e tão depressa encontrando uma relação factual nesse processo complexo da comunicação audiovisual juntamente com seus fãs. A pesquisa ouviu ao todo 298 crianças do fundamental I, e dentre elas, $85 \%$ tem por preferidos os desenhos discorridos mais 


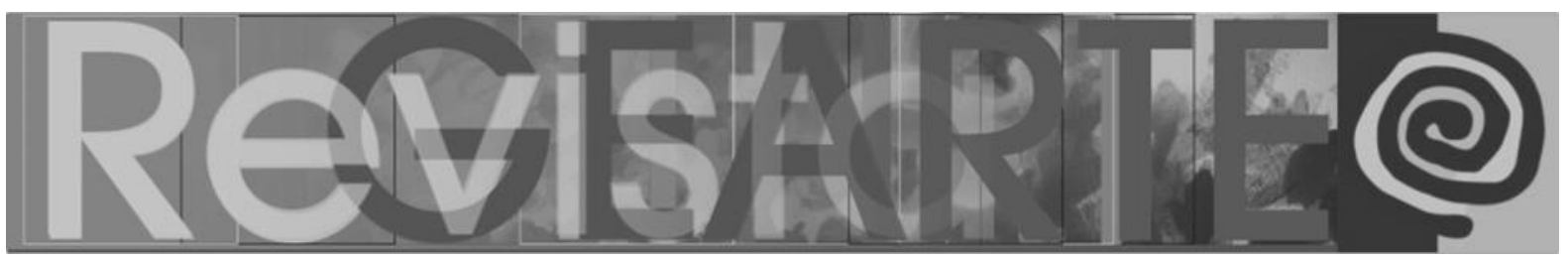

adiante na pesquisa, a saber, "Avatar, a lenda de Aang", "Dragon Ball" e "Naruto", tornando-os, o que podemos denominar juntamente com Machado (2000), o corpus, a parte integradora do conjunto de experiências dentro da televisão para a pesquisa.

Ao se falar das animações, que hoje constituem parte da televisão e da internet que crianças e jovens que participaram da pesquisa mais consomem, é quase impossível deixar de lado as questões cinematográficas, visto que "a história da animação está imbricada na história do cinema" (ROCHA, 2008, p.14), sua própria origem está nele, tanto ocidental quanto oriental. Todavia, ao referenciar o cinema ou excertos sobre tal, salienta-se que o texto faz menção as produções que posteriormente foram difundidas na televisão e, mais adiante, na internet.

\section{Interações sociais e nutrição imagética: o galgar do processo criativo}

Para que haja criação, não basta somente se nutrir constantemente de toda a sorte de imagens, sejam elas visuais, sonoras, olfativas, gustativas ou táteis, em "uma acumulação estéril" (MORIN, 2001, p.24), nem também fazer com que elas sejam meras apreensões dentro do arcabouço cerebral. Ao contrário, é preciso que esses estímulos sejam elementos que se reconfiguram em constante devir dentro do sistema nervoso.

Já não se pode dizer que a sociedade atual é uma representação viva e factual que simplesmente imita os acontecimentos de outrora; a sociedade na qual se vive é uma nova configuração de um mundo que se transforma a cada dia, que se desvencilha de algo e agrega tantas outras coisas, com novas roupagens e conhecimentos. O sujeito coetâneo se conforma desde seu nascimento dentro de uma nova realidade que o impele a buscar novos sentidos, ações e assimilações diante das produções comunicacionais:

Se hoje temos o conhecimento de uma audiência com múltiplas mediações, e que, segundo Orozco, transformou o receptor passivo em um sujeito ativo e criativo, capaz de ressignificar e reenviar mensagens, entendemos que foi esse o resultado das significativas mudanças que atingiram e ainda atingem nossa sociedade (PRADO e MUNGIOLI, 2016, p.91). 


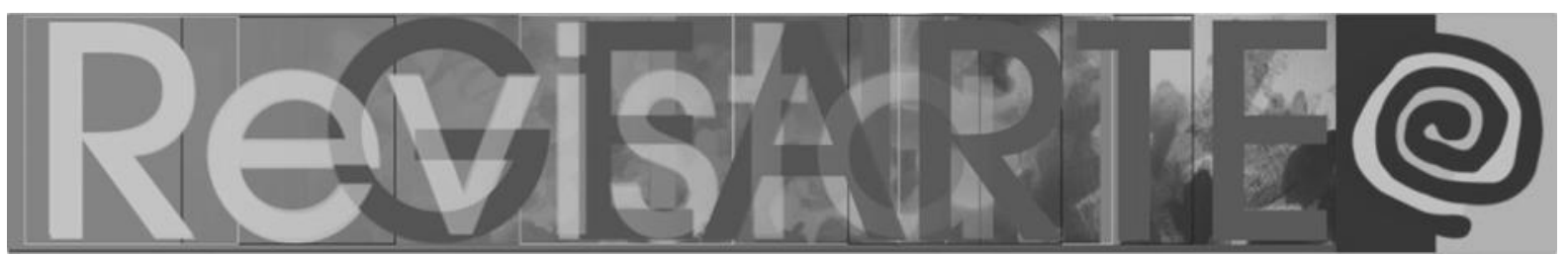

Atualmente inúmeras produções são feitas para o cinema e a televisão, aumentando cada vez mais a quantidade de consumidores, ao passo que potencializam experiências emocionais e a existência de um diálogo com questões atinentes ao espectador, podendo levá-lo a um desfecho de ação reflexiva e não passiva. Para Dietrich, "experiências emocionais intensas criam uma forte necessidade de expressão criativa" (DIETRICH, 2004 apud XIMENDES, 2010, p. 87). Espectador pode experienciar, de acordo com seu nível de atenção, momentos emocionantes diante dos audiovisuais, consequentemente pode-se vir em uma necessidade expressiva de criar a partir do que vivenciara.

De acordo com Machado (2000, p.197) com a popularização da televisão, a difusão exacerbada de informações e saberes advindos dos diversos produtos massivamente produzidos, "do intelectual ao agricultor, do executivo à dona de casa, todos indistintamente podem provar o gostinho desse fino biscoito de confeitaria que Oswald de Andrade queria democratizar para toda a sociedade". A população, tão depressa, agora tem um novo aliado na busca por informações e conhecimentos e, em sua própria construção como sujeito dentro do âmbito social, uma vez que a televisão passou a ser "uma referência importante dentro da cultura de nosso tempo" (MACHADO, 2000, 16).

Segundo a psicóloga Wechsler (2002), vários fatores influenciam o processo e a expressão do potencial criativo, sendo o ambiente circundante ao ser humano um dos grandes propulsores para tal ação. O cérebro absorve muito das coisas que o ambiente propicia; informações significativas propiciadas constantemente são consolidadas internamente, e quando há a necessidade de evocá-las, os fragmentos espalhados por esse arcabouço cerebral são trazidos à tona.

Dialogando com Morin, há um pensamento complexo dentro dos produtos audiovisuais advindos dessa cultura, que é o próprio produto criativo, o que consequentemente propicia uma gama de possibilidades para o indivíduo reter as informações narrativas, visuais e sonoras, e tão logo constituir um arcabouço muito 


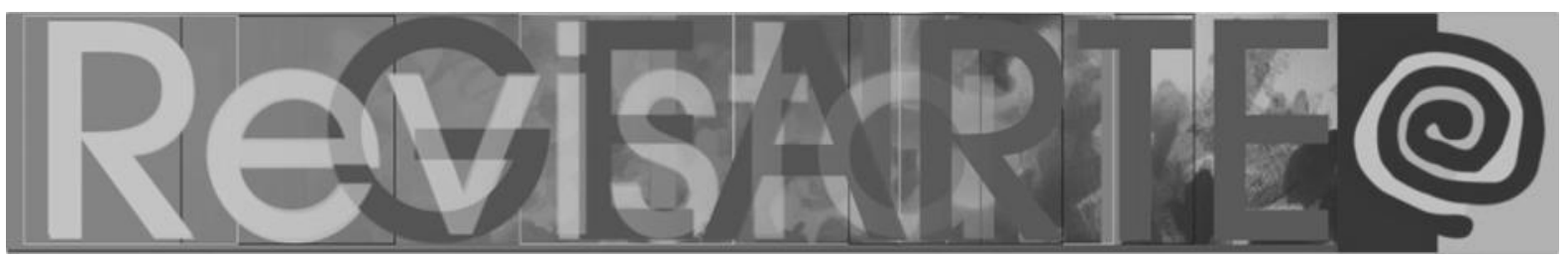

mais propício para articular, mover, configurar imagens e externalizá-las criativamente por meio de infindas possibilidades criativas.

O pensamento complexo que preconizara Morin (2003, p.15) consiste em não "compreender o ser humano apenas através dos elementos que o constituem", mas o conhecer dentro de uma sociedade em que "há interações entre indivíduos" e que entre eles "formam um conjunto e a sociedade, como tal, é possuidora de uma língua e de uma cultura que transmite aos indivíduos". Somos seres trinitários, dotados de capacidades que se conformam através da própria individualidade, de uma espécie biológica e do âmbito social, fazendo com que nossa unicidade seja múltipla e vice versa (MORIN, 2003).

\section{Sistema Nervoso Central: breves informações}

O cérebro é arcabouço com quase que infindas redes de conexões, chamadas de neurônios; ao passo que essas redes são interligadas, conectadas e acionadas, as ações —falas, pensamentos, memória, aprendizagem, comportamentos e etc.começam a, cada vez mais, serem requintadas, tornando-se uma estrutura qualitativa que congrega as imprescindibilidades da vida humana. A saber, processos emocionais, sociais, químicos, físicos e fisiológicos (DAMÀSIO, 2012; COSENSA E GUERRA, 2013; RAMACHANDRAN, 2014).

Figura 1- Hemisférios cerebrais visto de cima

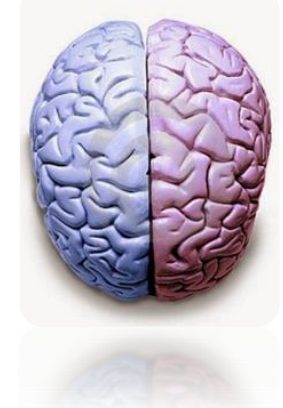

Fonte: http://cristalfanucci.blogspot.com/2014/12/radiestesia-e-radionica.html

Com o galgar dos estudos, ficou claro que o hemisfério esquerdo "processa melhor as informações de maneira sequencial, lógica, linear, detalhista, organizada e 


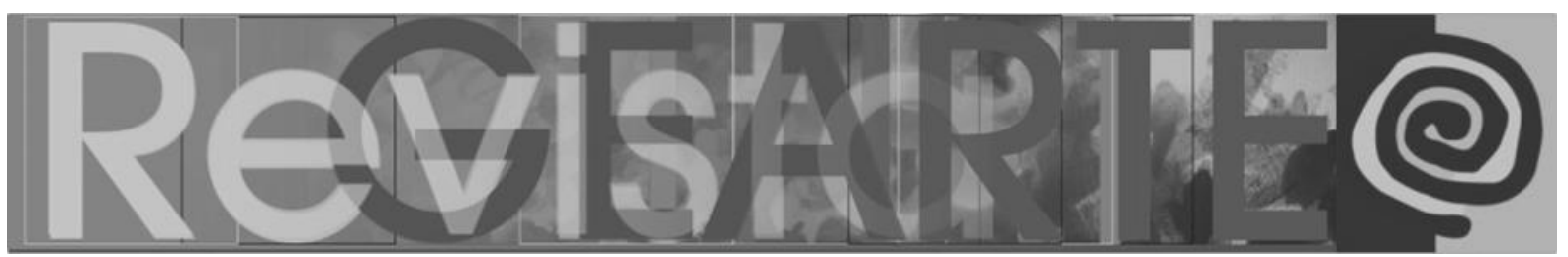

analítica" (WECHSLER, 2002, p.43). Expressões verbais, matemática, computação ou aritmética, leitura, lógica e recordação de fatos ou situações passadas com o uso de material verbal, compõem o rol das funções delegadas a essa área cerebral.

Nas especificidades do funcionamento do hemisfério direito concentram-se o processamento de informações de maneira holística, sem lógica, não linear e emocional. Irromper pensamentos em um momento qualquer, sonhar acordado, apreender por meio de experiências tangíveis, utilizar analogias e metáforas, intepretação da linguagem corporal, desenhar e fruir de qualquer material visual complementam as funções desse hemisfério (WECHSLER, 2002).

Para que toda essa maquinaria tenha seu desenvolvimento pleno, além dos fatores internos que constituem o ser humano, fatores externos participam grandemente nessa ampliação, inclusive as produções audiovisuais, que hoje pelos avanços tecnológicos e digitais, já não mais trabalham com uma área sensorial em detrimento de outra. Elas congregam um constructo de informações que estimulam diversos campos, tanto a visão, como audição, em um pensamento argumentativo, linear ou não, construtivo, ativo, reflexivo. De forma ampla, uma vez que somos indivíduos dentro do complexo social em que a comunicação, a televisão constitui parte fundante nesse processo de interação, "com a sua cultura, com os seus interditos, com as suas normas, com as suas leis, com as suas regras", ela nos produz concomitantemente "como indivíduos e, uma vez mais, somos produtos produtores", além de não sermos somente uma ínfima "parte de um todo, o todo social, mas que esse todo está no interior de nós próprios" (MORIN, 2003, p.17).

Segundo Paul Torrance (1982) apud Wechsler (2001) acreditava-se que o hemisfério direito, supracitado, imperava preponderantemente no processo criativo, porém, no galgar das pesquisas, percebeu-se "que os dois tipos de processamento, direito e esquerdo, contribuem, em etapas diferentes, para a produção criativa" (p.151). 


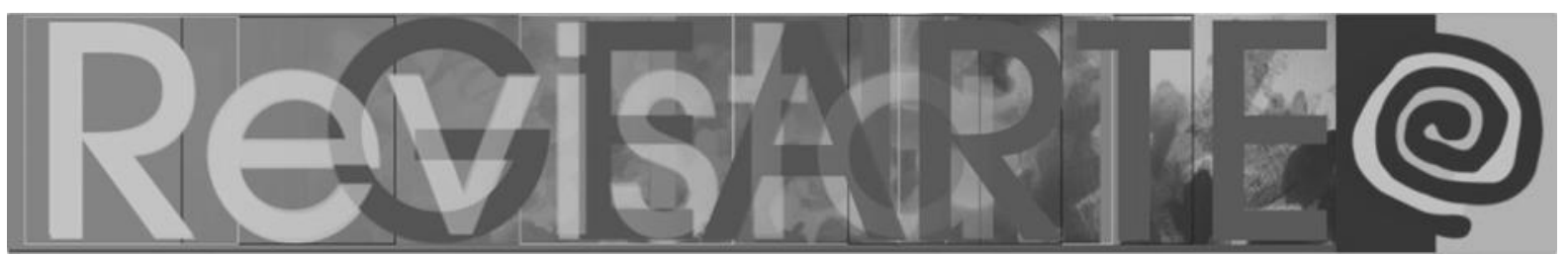

Para o autor supracitado, em primeiro momento o hemisfério direito contemplaria os elementos experienciados de forma holística, emocional, intuitiva, fluente e flexível, e frente a ele, as ações posteriores seriam atreladas na busca de configurações e reconfigurações imagéticas.

O hemisfério esquerdo sucede a essas etapas fazendo uma ampla análise das soluções encontradas, alterando-as, julgando-as e formando-as para dar cabo a uma produção final criativa. Em paralelo aos textos de Torrance, os espanhóis Marcos Nadal Roberts e Albert Flexas Oliver (2012) concluem que as atividades advindas do campo da criatividade "(...) implicam regiões do cérebro relacionadas com a tomada de decisões, a percepção, a memória, a atenção" e as emoções, e “(...), nenhuma destas regiões participa de maneira exclusiva neste tipo de tarefa (...), é um resultado da ação integrada de processos cognitivos e afetivos (ROBERTS; OLIVER, p.99, 2012), do hemisfério direito com o esquerdo do cérebro. Dietrich soma-se aos seus escritos, validando tal tangibilidade de pesquisa, além de salientar que a produção de novidades (criação) pode ocorrer tanto em estruturas emocionais quanto cognitivas (LIMA JÚNIOR, 2015).

Para Houzel (2012), a base da imaginação, ação anterior ao ato criativo, é a sensação, que se constitui por intermédio das experiências e incute um neurônio ou conjunto de neurônios que respondam as imagens evocadas. Em concomitância com experiências animais, a autora salienta que:

(...) O cérebro não nasce com neurônios para todos os objetos possíveis: ele vai aprendendo de acordo com o que vivencia. No cérebro de um macaco que nunca viu pássaros, por exemplo, não há neurônios que reconheçam araras. E sem neurônios que reconheçam araras, como imaginar uma arara? (HOUZEL, 2012, p.162).

Em sequência, se há nutrição imagética, há imaginação, e se nesse processo houver uma ação mental mais apurada, reflexiva e distante das padronizações atuais, tão logo existirá um ato criativo. Somando às ideias de Houzel, Izquierdo (2011, p.127) salienta que a criatividade, como a advinda dos artistas, seria uma "composição de memórias, mas que não é igual à soma de suas partes", mas a reconfiguração de tais 


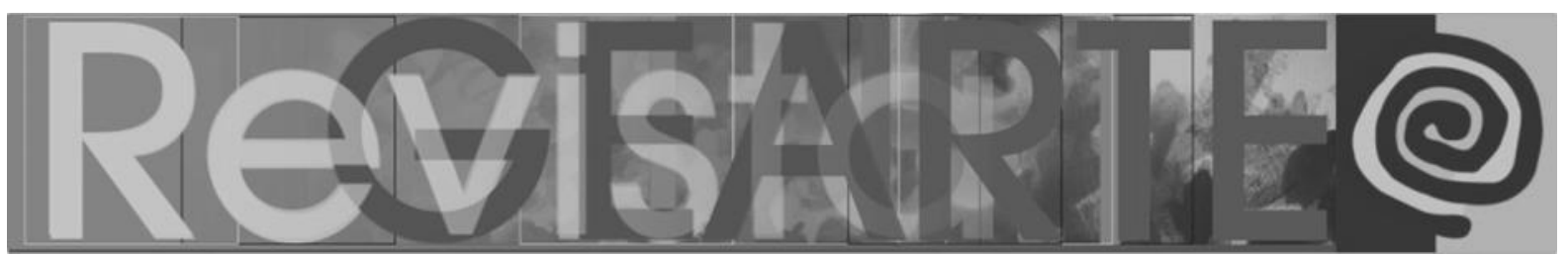

imagens, a seleção de determinadas partes da imagem, tornando-as novas diante das que outrora se constituíam. De fato, um verdadeiro conhecimento criador, que "(...) dialetiza sem cessar a permeabilidade observador-observado, 'subtraindo' e 'acrescentando' (MORIN, 1997, p.21), mas não uma adição e subtração de uma área pobre, entretanto nutrida pelas informações circundantes, permeando as imagens internas do espectador com as experiências externas, e tão depressa consolidando uma extensão de experiências.

A comunicação audiovisual dentro de aspectos socioculturais e históricos da contemporaneidade passa a ser útil, de extrema importância para os estudos da criatividade ao passo que ela carrega elementos subjacentes e indicativos de uma nova organização de memórias, entrelaçamentos e materialização de tal ato; faz com que os olhares venham resgatar "a inteligência, a criatividade, o espírito crítico e tudo isso que tem ficado reprimido na maioria das abordagens tradicionais (...)" (MACHADO, 2000, p.21). Entender a complexidade com que se deu a configuração de um produto audiovisual é também compreender como o ato criativo em si se dá, pois ao analisar perspicazmente todo seu constructo, suas nuances, indo da parte para o todo e do todo para as partes, nota-se que existiu um caminho, que não foi fácil nem rápido, mas entrelaçado com quase que infindas tramas que se congregaram para formá-lo.

Nessa compreensão, à época das grandes produções de massas, que já não se aceita mais o padrão monótono na construção de uma narrativa visual e sonora dentro das animações, visto que os meios tecnológicos alçam e possibilitam cada vez maiores vôos, esmiuçar um produto e suas ressonâncias dentro do âmbito de seus fãs é tarefa plausível. Diante disso, nota-se um caminho de mão dupla, um nutrir imagético através das produções animadas e um criar cada vez mais instaurado pelas fantasias e desejos do inconsciente trazidos a tona, e nesse devir, segundo Prado e Trinta (2018, p.54), “(...) a influência do imaginário se dá de forma cada vez mais intensa, visto que o inventário de possibilidades, de porte tecnoestético e expressão artística, que o alimenta -tal como o evidencia a animação- só faz ampliar-se". 


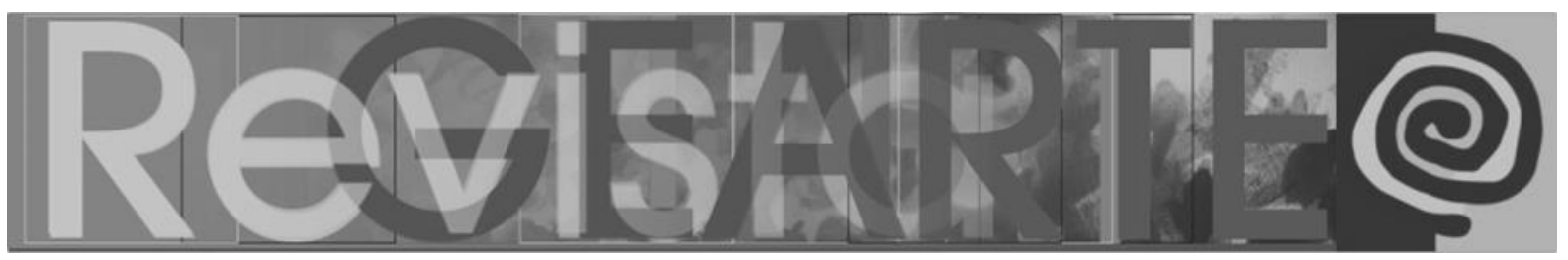

\section{Processos subjacentes: interlocuções com algumas animações}

Ao se referir à cultura de massas, Morin se vale de longos escritos para compor seu arcabouço textual discutindo da forma mais elucidativa possível ao leitor, ao passo que dialoga com os prós e os contras da sociedade atual em constante mudança e profusão de produções capitalistas, criativas e culturais. Em paralelo, ao discorrer sobre o método, medida pela qual se segue a fim de chegar a algum lugar, reitera e defende o posicionamento e as ações da cultura de massas, argumentando que, "é preciso seguir a cultura de massa, no seu perpétuo movimento da técnica à alma humana da alma humana à técnica (...)" (MORIN, 1987, p.21), legitimando a necessidade de uma interlocução entre fatores endógenos e exógenos que constituem os seres humanos e suas conseqüentes ações dentro do âmbito social.

As animações, que após serem gestadas e produzidas no ocidente e mais tarde chegaram ao japão, não eram mais produtos criativos de pequenos nichos sociais, mas passaram a ser qualificadas cada vez mais pelos equipamentos e a serem produzidas massivamente, imitando a alma humana e reinventando-a (ROCHA, 2008: PRADO, TRINTA, 2018).

O assenhorear-se sobre informações das produções de algumas animações para posteriormente falar do diálogo que se estabelece entre a criança, os fãs e as produções em massa que são passadas na televisão, é de suma importância, visto que, "Para pensar localizadamente, é preciso pensar globalmente, como para pensar globalmente é preciso pensar localizadamente" (MORIN, 2001, p.25). As produções televisivas, como alguns outros meios da sociedade atual, trazem o globo para a unicidade de cada fã que a ela se prostra ativa e reflexivamente, uma vez que "o acervo de obras criativas e inquietantes produzido pela televisão não é maior nem menor do que aquele acumulado em outras linguagens (...)", com "trabalhos complexos" (MACHADO, p.10, 2000). 


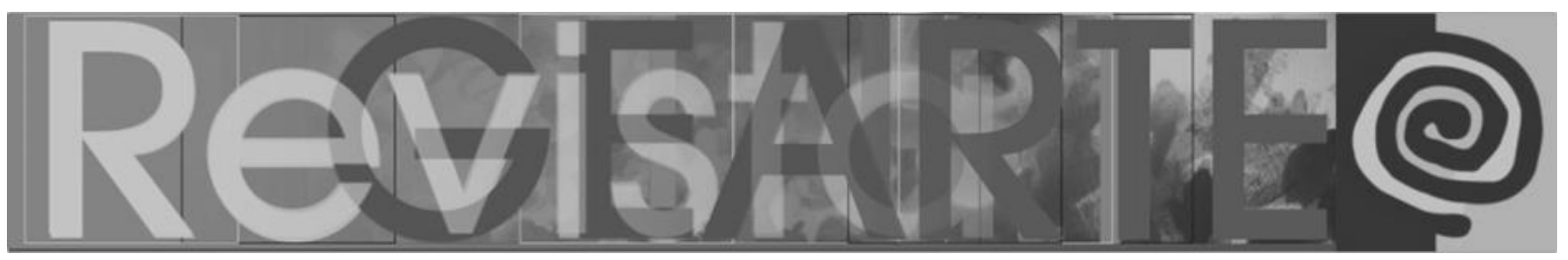

\section{Avatar, a lenda de Aang}

Acordado com tal perspectiva supracitada, os criadores de Avatar, a lenda de Aang $^{1}$ (Bryan Konetzko E Mike DiMartino), um desenho consumido grandemente pelo público infanto-juvenil desta pesquisa, nessa grande empreitada criativa, eles chegaram a viajar até a Coréia para estudar todas as lendas e as artes marciais de lá, fazendo com que todo o avultado de informações lá coletadas fossem os elementos que constituiriam a parte fundante de toda a narrativa que estava por gestar em suas mais auspiciosas produções, fazendo de fato com que o observador participasse "(...) do objeto de sua observação" (MORIN, 1997 p.21). Nota-se que o processo de criação da dupla de produtores não se pautou totalmente pelo vagar de suas vidas pregressas, mas sim pela inserção e busca de informações, conhecimentos e ações que os impelissem a imaginar, articular ideias e a criar uma de suas mais famosas animações.

A ideia, a princípio, era fazer uma história inspirada no pólo sul, estudando os documentários mais peculiares que relatam sobre as expedições na Antártida, informações essas que os levaram a incorporar tal paisagem gélida às moradias dos personagens intitulados dobradores de água. Todavia, as pesquisas se estenderam para outras localidades e culturas mundiais.

Entre paisagens das mais variadas possíveis, populações com culturas diferentes, remetendo desde as manifestações asiáticas, às indígenas, européias e africanas, dialogando entre os quatro elementos da natureza e a possibilidade de manipulá-los, criou-se a série A Lenda de Aang, uma obra totalmente integradora em questões concernentes a etnias, relevos, política e toda uma construção de uma sociedade em si.

A série se desenrola com a narrativa de um garoto que muito cedo descobre ser a pessoa com espírito divino que tem por função restaurar e manter o equilíbrio

1 Processos de criação de Bryan Konetzko $E$ Mike DiMartino, Disponível em: $<$ http://geracaoanimacao.com.br/os-avatares-da-nickelodeon-1de2-ga-03/>. Acesso em 10/2018. 


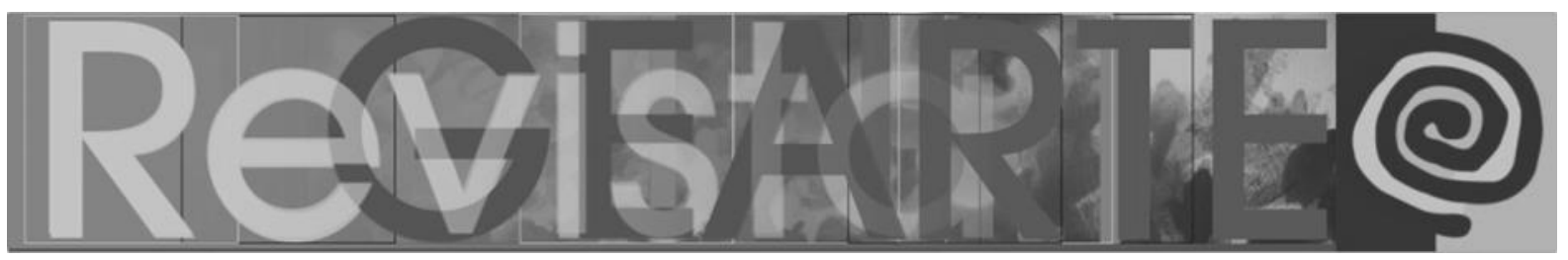

natural dos quatro elementos juntamente com as pessoas com os grandes nichos sociais de diferentes culturas.

\section{Dragon Ball}

A série Dragon Ball, desenvolvida primeiramente em mangá por Akira Toriyama, e posteriormente adaptada para a animação, conta a história de um menino chamado Goku. Ele se distingue dos demais personagens humanos, pois mora longe da civilização, possui uma força colossal e porta em seu corpo um rabo de macaco. A narrativa se segue na busca das esferas do dragão, que ao encontrá-las, a pessoa possuidora pode ter um desejo concedido. Paralela a essa narrativa, a história se pauta também na proteção do planeta e de seus habitantes (SILVA, 2005).

O processo de criação de Toryama se delineou a partir da fusão de uma lenda chinesa que discorria sobre sete esferas do dragão, juntamente com a lenda indiana sobre um macaco de pedra que torna-se humano, além de ter como prerrogativa um bastão mágico e a possibilidade de voar em uma nuvem (SILVA, 2005).

\section{Naruto}

A animação Naruto criada por Masashi Kishimoto, transmitida entre os anos de 1979 e 2005, pela Nippon Television, ainda concentra um expressivo número de espectadores ávidos por acompanhar e viajar nas mais emblemáticas narrativas constituídas dentro dos episódios. A série conta a história de um garoto órfão, Naruto Uzumaki, que tem por ação do destino carregar dentro de si uma raposa de nove caudas que outrora tentou destruir sua vila, levando-o a ser rejeitado pelos amigos e comunidade circundante. Toda a narrativa tem como objetivo mostrar a busca do personagem na conquista de tornar-se um poderoso ninja, enaltecido por todos (SILVA, 2012).

Ao criar o personagem e toda a narrativa que se transformou em uma longa série, Masashi Kishimoto passou por um processo de nutrição visual a partir das ações do personagem Goku, da série supracitada. De personalidade forte e marcante, Goku 


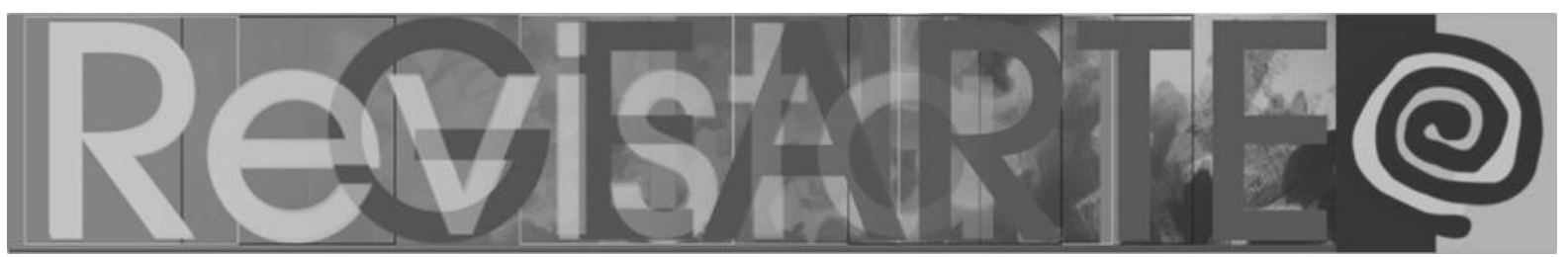

tornou-se inspiração primordial dentro do arcabouço imagético de Kishimoto, levandoo a criar Naruto em 1999, que, em 2002 receberia adaptação para animação. A animação Doraemon, criado por Fujiko Fujiio, também constituiu-se como fator imagético durante a infância e posterior inspiração para o criador de Naruto, validando a ideia inicial do texto de que "a animação se consuma como uma modalidade de representação, afetando instâncias do imaginário" (PRADO;TRINTA, 2018, 38).

Problematizando o sistema de estado e o privado, Edgard Morin salienta que aos desprover-se de uma intenção capitalista, "as possibilidades criadoras dos autores podem ser maiores do que no sistema capitalista, uma vez que as considerações a respeito de lucro comercial são secundárias nesse tipo de sistema (1997, p.28)". Para ele, infelizmente, parte da indústria cultural "atrai e prende por salários muito altos os jornalistas e escritores de talento: ela, porém, não faz frutificar senão a parte desse talento conciliável com os padrões (1997, p.32)", podando a parte fluida do ato criativo. Nota-se que o processo de criação dos desenhos supracitados de forma breve tem em comum sua possibilidade fluida, desprovida da égide cerceadora, quiçá, do sistema capitalista que conserva o trabalhador para produzir, não dando uma total liberdade para as ações criativas:

Assim, no que concerne ao cinema, o próprio modo de pensar reinante oculta à unidade complexa e a complementaridade do real e do imaginário, cada uma das noções excluindo necessariamente a outra. Da mesma forma, esse modo de pensar quebra, sob a forma de alternativas disjuntivas, aquilo que é a própria originalidade do cinema: o fato de ele ser ao mesmo tempo arte e indústria, ao mesmo tempo fenômeno social e fenômeno estético, fenômeno que remete ao mesmo tempo à modernidade do nosso tempo e ao arcaísmo dos nossos espíritos (MORIN, 2014, p.14:15).

Com vistas ao excerto acima, pode depreender-se um pouco mais além da complexidade das produções, inserindo às elucubrações o pensamento sobre a própria constituição do ato criativo de tais produtores, que nele está incluso tanto o ser imaterial de quem cria no que concerne à amores, dissabores, previsões e tantas outras sortes de pensamento, quanto o próprio meio social no qual está inserido, sendo ele compelido a instaurar tal complexo dentro dos produtos audiovisuais que serão passados na televisão. Fica evidente, diante e dentro de todo o galgar desse 


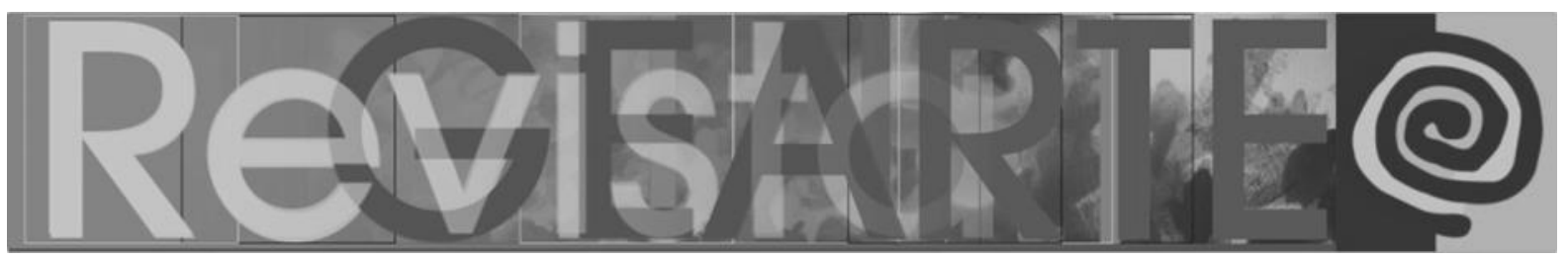

processo e seu produto final, que esse todo em um sistema tecido junto com múltiplos membros e particularidades "é mais que a soma das partes, isto é, no nível do todo organizado há emergências e qualidades que não existem no nível das partes quando são isolados" (MORIN, 1999, p.28). No acelerado crescimento de criações das mais distintas formas de animações, todos os meios que são inventados e qualificados cada vez mais pelos sistemas tecnológicos contemporâneos impelem configurações de desenhos animados cada vez mais complexos, articulando os fatores que constituem o produtor internamente com os que o circunda. Tais estruturações tendem a crescer cada vez mais.

Nas animações, não há meras representações do arcaísmo somente, do presente ou do futuro, mas uma articulação que ora impele os olhares ao que se passou e ora os lança ao futuro, talvez, próximo. São elementos imbricados que de alguma forma dialogam com sociedades pregressas, com o que se vive e concomitantemente com o que se espera de uma nova qualificação estrutural da sociedade vigente. Claro que não no sentido de poderes superfantásticos como possuem os protagonistas, todavia na ideia de dispositivos que mantenham um equilíbrio biossociocultural e subsidiem nos inúmeros anseios emergentes em uma sociedade conformada na era tecnológica.

\section{Nutrição, memória e imaginação: convergência harmônica entre televisão e criança/fã}

Ao se inter-relacionar com diversos constructos sensoriais advindos do meio externo, as áreas cerebrais assimilam e consequentemente criam memórias sobre tais interações, sejam elas significativas de forma positiva ou negativa. Em um desenho animado ou outro tipo de produção, o espectador está diante de estímulos que o impelem a olhar mais, ouvir mais e tão logo, a imaginar possibilidades de como o enredo terá seu desfecho na resolução dos problemas que se organizam em tais obras e, ou tantas outras possibilidades imaginadas por ele. 


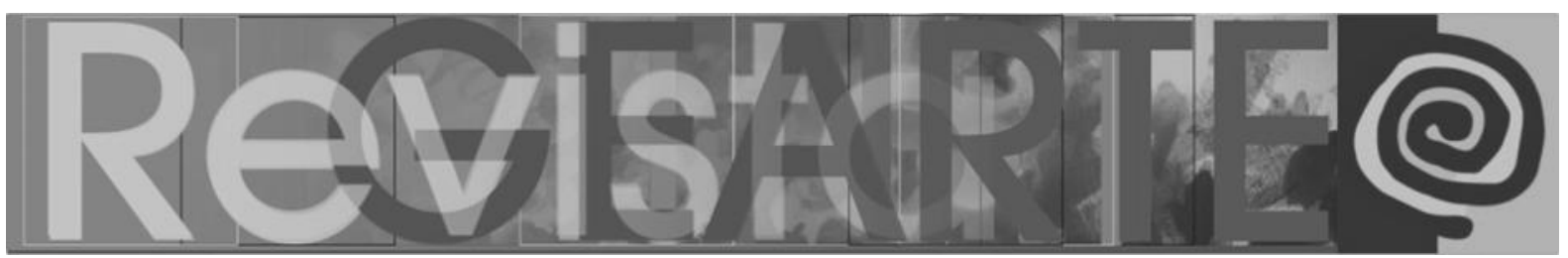

Dentro desse contexto que a criança está inserida acontece o que Huergo (1997) apud Baccega (2001) atribuiu como sendo uma alfabetização pós-moderna, ação concernente ao aprender a ler os diversos estímulos dos produtos audiovisuais propiciados pela televisão, "na qual eles se banham e da qual aprendem" (BACCEGA, 2001, p.11) e, consequentemente se constituem como ser dotado de saberes imagéticos consolidado em sua memória para o ato imaginativo, e tão logo, criador. Pois, a nossa sociedade cultural e atual está marcadamente pelas projeções midiáticas, inclusive as animações, "(...) está impregnada desse novo jeito de pensar, de construir o imaginário" (BACCEGA, 2001, p.9).

Mas para construir esse imaginário, para reter essas informações dispostas, Morin (1999, p.25) salienta que:

(...) quando captamos uma informação na televisão ou nos jornais, para conhecê-la, para compreendê-la, temos que contextualizá-la, globalizá-la. Nós a compreendemos a partir do seu contexto, e se ela faz parte de um sistema, tentamos situá-la nesse sistema.

Não se trata de um receber informações de forma inócua, mas deveras um vai e vem constante, onde espectadores congregam suas mais complexas estruturas de conhecimentos e dialoga com as que recebem dos meios audiovisuais, em uma verdadeira trama que vai se costurando como suporte em seu âmbito.

Prontamente, produções audiovisuais como as de "Avatar, a lenda de Aang", "Dragon Ball Z", "Naruto", e dentre tantas outras, podem contribuir para desenvolver um pensamento criativo nos fãs, uma vez que lhes inspiram a participação reflexiva e ativa, com opiniões e ações, em diversos aspectos imbricados nas próprias narrativas. Essa inter-relação que se estabelece ao lidar com a mídia subsidia no desenvolvimento de diferentes habilidades, visto que ao consumir tais produtos o espectador não se prostra de forma passiva diante das imagens e dos sons, todavia seu cérebro assimila e absorve por diferentes áreas as informações que ali estão sendo expostas. Há o que Pillar (2010) denomina de contaminação, não no sentido 


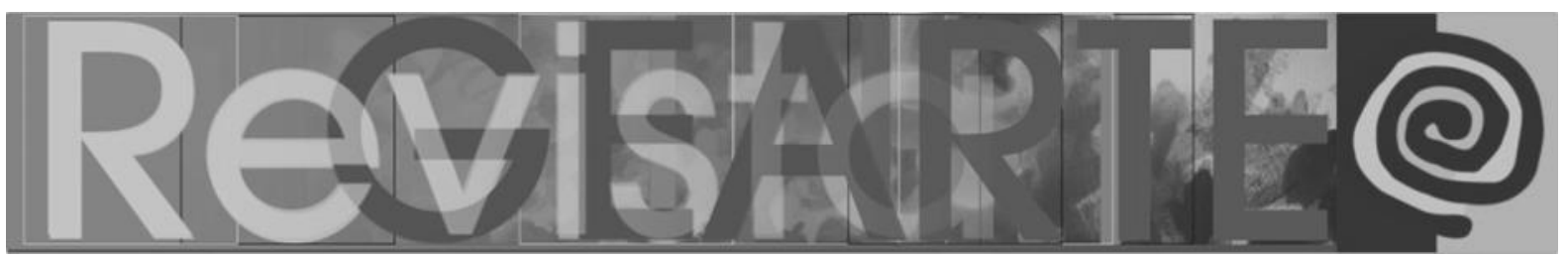

negativo, mas no pensar que existe uma permeabilidade entre as Artes, sejam elas das crianças ou das animações, além do próprio sujeito com as produções.

Figura 2 e 3 - Da esquerda para a direta, desenho de menina com 7 anos que consome animações japonesas e, menino de 6 anos que consome as produções de Naruto

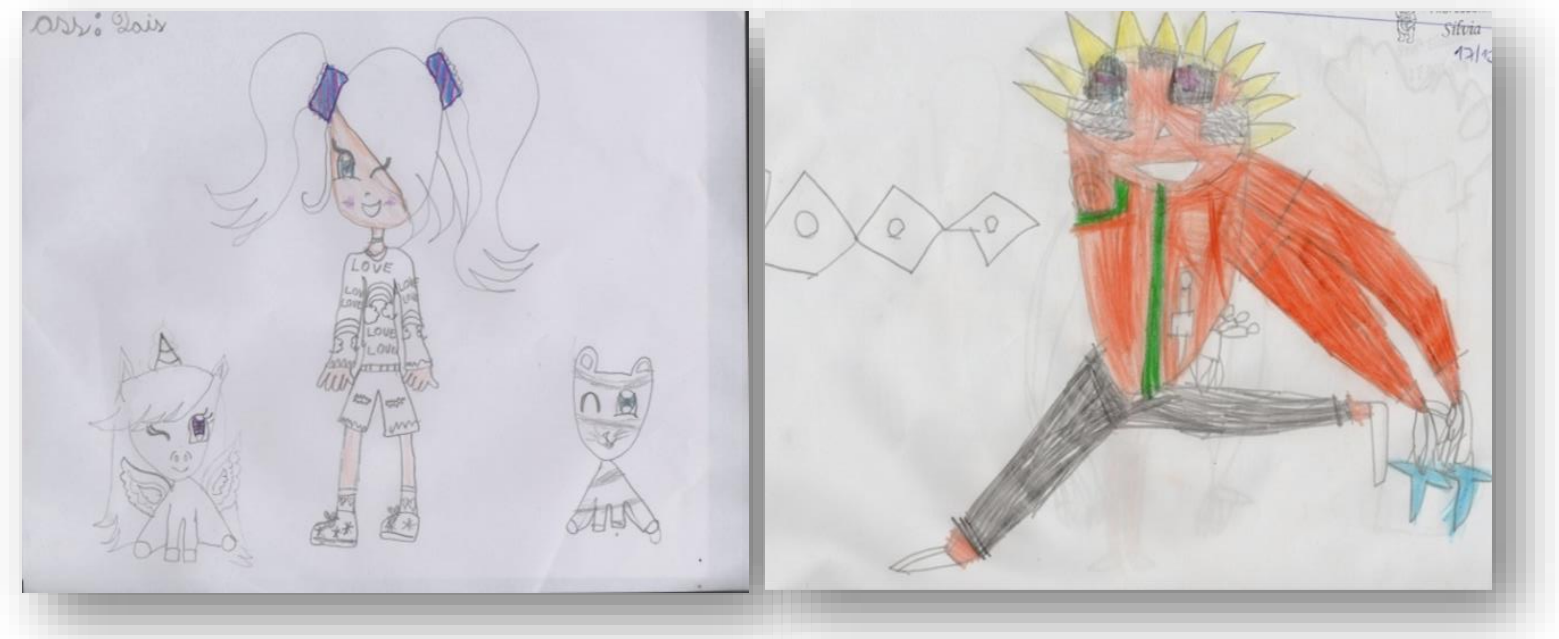

Fonte: Acervo Pessoal.

Seria ingênuo pensar na total desarticulação do meio com o ser, da televisão que constitui hoje esse meio e a criança como fã, hoje imersa nas grandes produções de massa, dentro do complexo midiático que se estende continuamente. A sociedade "está em nós" e "somos uma pequena parte da sociedade", e tão depressa, "esta concepção de pensamento dá-nos uma lição de prudência, de método e de modéstia" (MORIN, 2003, p.17). Das mais simples às mais belas obras de arte, sejam cinematográficas, televisivas ou não, elas “(...) devem ser consideradas não apenas, nem principalmente, objetos de análises gramaticais, sintáticas ou semióticas, mas também escolas de vida, em seus múltiplos sentidos" (MORIN, 2001, p.48), constituindo parte indissociável na conformação do ser social. Tanto a vida quanto as produções animadas carregam um conglomerado de um sincretismo textual, de textos ora visuais, ora sonoros, ora escritos, e em constante devir, elas se unem, se hibridizam.

Dentro de uma proposta tematizada, a criança abaixo criou sua produção gráfica congregando variadas formas visuais encontradas nas animações que 


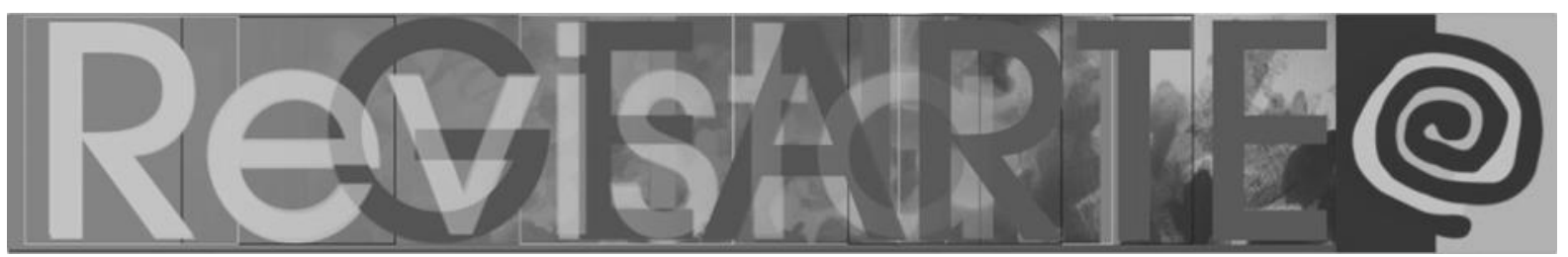

consome diariamente. Dragon Ball $\mathrm{Z}$ e o desenho dos vingadores os estimula de forma expressiva a se atentar a narrativa e as configurações de todo o desenho. Em sua representação, percebe-se evidentemente ressonâncias da cumplicidade encontrada em "os vingadores"; notam-se olhos salientes destacados nos desenhos de "Dragon Ball" e, um estilo de vestuário e intenção de movimento muito característico nos grandes lutadores de tais desenhos, como também nos próprios monstros encontrados nas animações de "Ben 10".

Figura 4-Da esquerda para a direta, e desenhos abaixo; Desenvolvimento do personagem Goku de Dragon Ball; Desenho feito por criança de 5 anos; Monstros do Ben 10

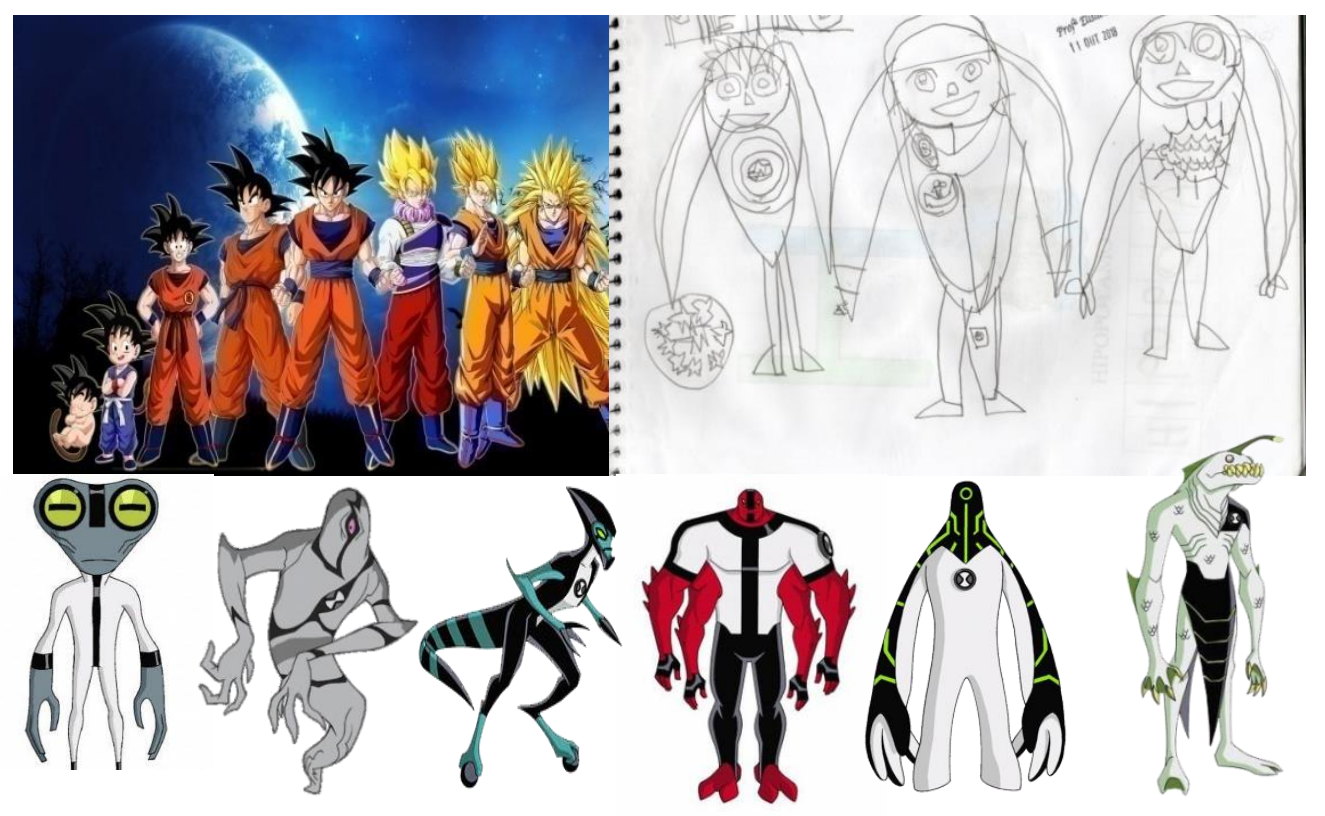

Fonte: Elaboração e acervo do Autor.

No desenho acima, não existe uma simples cópia de uma animação em detrimento de outra, mas uma reconfiguração das formas visuais condensadas em uma nova expressão gráfica, que para Izquierdo (2011, p.127) é "uma composição de memórias, mas que não é igual à soma de suas partes", mas uma mistura de memórias. E para acordar com a fala de Morin (1999, p.30-31), tal desenho se evidencia como "(...) a união da simplicidade com a complexidade", as partes de um membro compondo um novo, agora, de forma indissociável. 


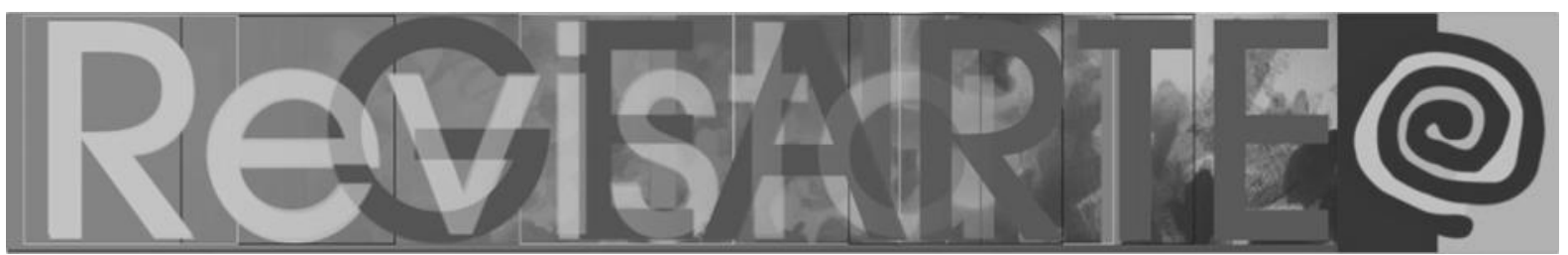

A luta de dominação apresentada em "Avatar, a lenda de Aang" mistura as crenças de equilíbrio espiritual oriental juntamente com a conquista do controle humano, uma aprendizagem sobre o Eu interior. A criança que criou o desenho seguinte, o desenvolveu a partir de uma aula sobre cultura egípcia e a utilização do papiro como suporte para hieróglifos. Nota-se a conformação da proposta articulando os movimentos de lutas da série que ele teve contato, com o cânone egípcio aprendido na aula. Os meios que se tornaram indissociáveis em sua formação como criança/estudante, construíram uma alfabetização visual múltipla para o ato criador, pois as próprias animações encontradas na televisão:

(...) elaboram novas formas de conhecimento, que não pode ser recortada, organizada e controlada (...), múltiplos e diferentes modos de comunicação que por sua vez suscitam múltiplas e diferentes estruturações da percepção, e esta co-evolução produz múltiplos e diferentes imaginários (BACCEGA, 2001, p.9).

Figura 5 e 6 - Da esquerda para a direita: Pergaminho de luta para pessoas com poderes de dominar a água (a) e desenho de criança de 10 anos (b)
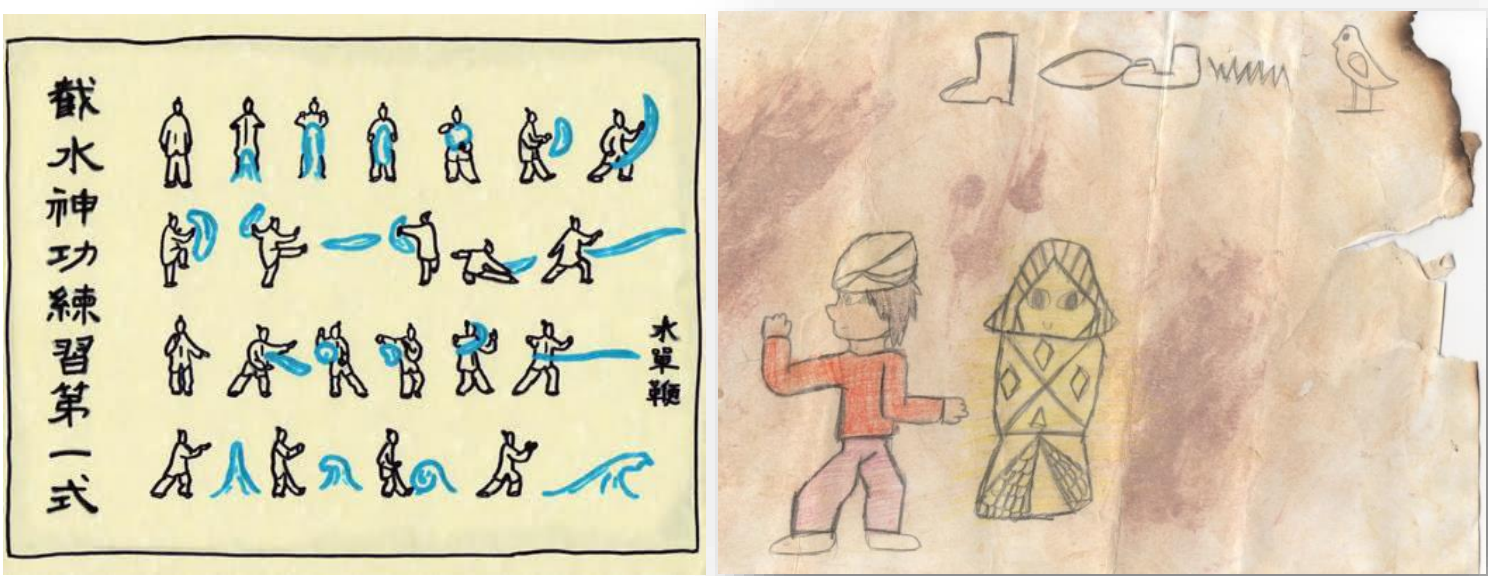

Fonte (a): Disponível em http://avatar-a-lenda.forumeiros.com/t33-poderes-habilidades-dosdobradores-de-agua. Fonte (b): Acervo pessoal.

Afeitos à animação, a criança, que com vagar se torna um fã pelas produções, cresce e se desenvolve ao dialogar constantemente com os produtos que lhes vão sendo apresentados, que em uma pesquisa rápida pela internet por algum tipo de saber, pela curiosidade ao clicar nos botões do controle da televisão em busca do lúdico, ela vai investigando atrás daquilo que Ihe interessa, que lhe chama atenção, e 


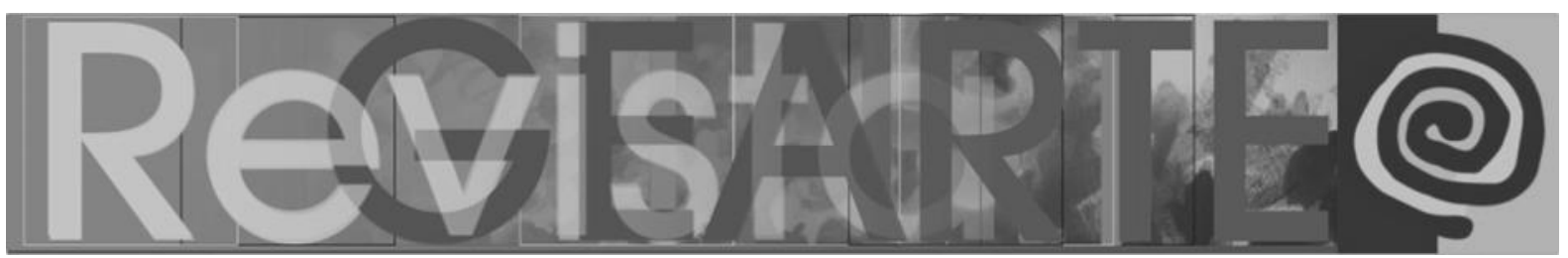

nesse investigar transita em um constante devir, incessante imaginar, um nutrir para a criação. Nessa lançadeira e imersão nas paisagens audiovisuais ela pode conhecer a si mesmo, o certo e o errado e os caminhos a serem escolhidos:

Assim, o bem e o mal estão dentro da criança. Ela é boa e má ao mesmo tempo. Como todos nós. Portanto, dentro dela existem monstros que a assustam e é através desses jogos, o lúdico, que ela os exorciza. Mas é também através dos monstros dos filmes de terror (PACHECO, 1995, p.46).

Naruto Ihes chama atenção, pois não é uma mera representação de um herói bonzinho que salva o mundo e fim. Ele cativa as crianças, pois sendo também uma em transição para a pré-adolescência, luta pelos seus objetivos ao passo que subverte as regras, brinca, e se apaixona, nutrindo o imaginário de quem o assiste, em busca de aventuras sem fim. Para Pacheco, "conhecer a criança é pensá-la interagindo dinamicamente, influenciando e sendo influenciada" (PACHECO, 1998, p.32), por exemplo, pelas diversas animações com que ela tem contato, tornando-a um ser que transita entre o imaginário das produções e sua própria realidade; que imerge na paisagem quase que infindável das animações e traz consigo um vasto repertório de imagens e possibilidades de criação. Nessas mesmas produções, nota-se que "na cultura de massa não há descontinuidade entre arte e vida" (MORIN, 1997, p.18), pois o todo apresentado nos desenhos dialoga com a unicidade da criança, ao tempo em que sua unicidade compõe uma identificação, levando-a a internalizar as questões atinentes as suas experiências ali presentes juntamente às alheias a sua vida, uma vez que, segundo Morin (1997) "esse consumo é psíquico". 


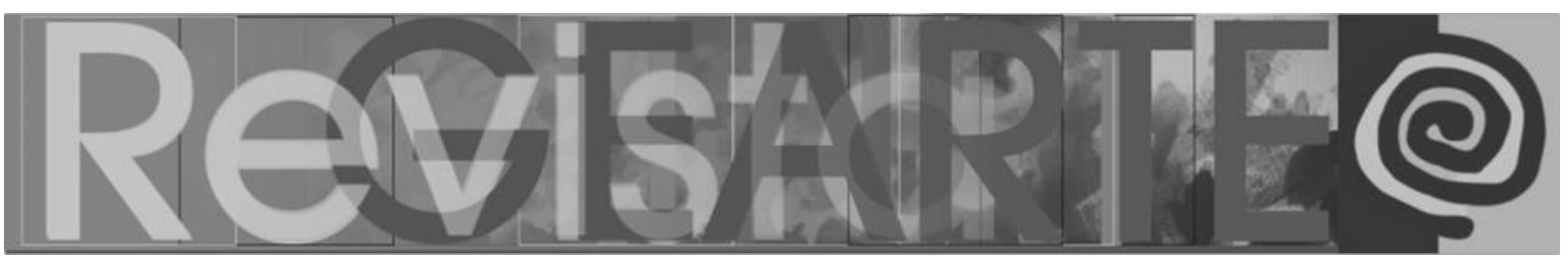

Figura 7 e 8 - Da esquerda para a direita: Naruto em posição de combate (a) e desenho feito por criança de 5 anos, fã dos desenhos de Naruto (b)
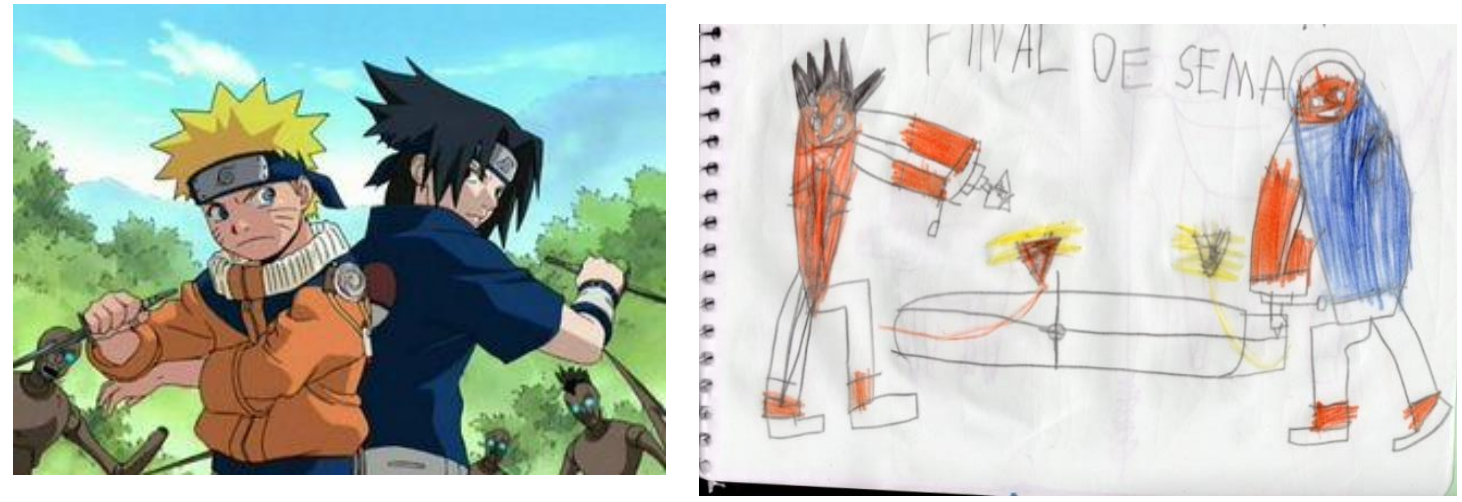

Fonte (a): Disponível em http://pudim.info/wiki/Naruto_vs._Sasuke.

Fonte (b): Acervo pessoal.

É importante destacar que tanto o desenho acima como os demais dispostos no texto, não são desenhos de livre expressão, mas propostas mediadas dentro da sala de aula, com um tema totalmente dispare à Arte das animações, porém que foram criados a partir da estética visual/narrativa nelas dispersas. Nota-se que a criança não copiou naruto, mas configurou uma atividade pedida pela professora com base nas cores e formas advindas do desenho que mais consome, segundo ela, dentro de casa, "uma vez que as fontes de aprendizagem se multiplicam cada vez mais na televisão" (BACCEGA, 2001, p.10).

As produções animadas, em todo seu arcabouço imagético com faturas de imagens e sons que "envolvem e embebem a alma" (MORIN, 2014, p.123), trazem uma imensa gama de composições que nutre o repertório de quem assiste, consequentemente inserindo fatores que constituir-se-ão partes precursoras em um ato criativo, visto que criação não se faz do nada. Baccega (2002) complementa a reflexão atribuindo à televisão um amplo valor, pensando de forma mais ampla, além das produções fílmicas, discorrendo que ela "conforma desejos, influencia a categorização dos anseios, generaliza particularidades, compõe o tecido da cultura. Educa" (BACCEGA, 2002, p.7). E integra Pillar às reflexões (2010, p.1930), que ao assistir; "experimentamos sensações, emoções, pensamentos provocados por este contato direto, que nos contagia, nos transforma". 


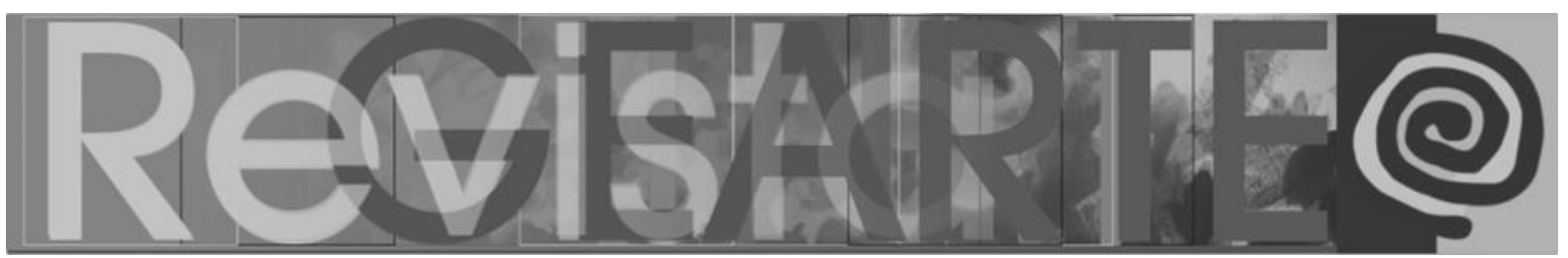

Nos projetos cada vez mais engenhosos, o homem vai além e de forma até então quase inimaginável; tira os pés dos homens da terra, levando-os na máquina denominada avião, veículo esse que ganharia cada vez mais notoriedade diante das grandes sociedades, pois até então fazia o homem voar sem ter asas, ser rápido sem se cansar. Todavia, foi somente o filme:

(...) que se projetou, cada vez mais alto, num céu de sonhos para o infinito das estrelas -das "stars"-, envolto em música, povoado de adoráveis e demoníacas presenças, escapando da terra a terra do qual ele deveria ser, segundo todas as aparências, o servidor e o espelho (MORIN, 2014 p. 23).

Sem uma análise mais detidamente das animações supracitadas, o desenho a seguir comporta-se com ressonâncias advindas das infindáveis estruturas imagéticas que permeiam o cotidiano midiático animado das crianças. Nota-se também que não há uma imitação, mas uma estruturação novel a partir de elementos visuais e narrativos encontrados nos meios televisivos.

Figura 9 - Desenhos criados por criança de 7 anos com a proposta sobre Música na escola

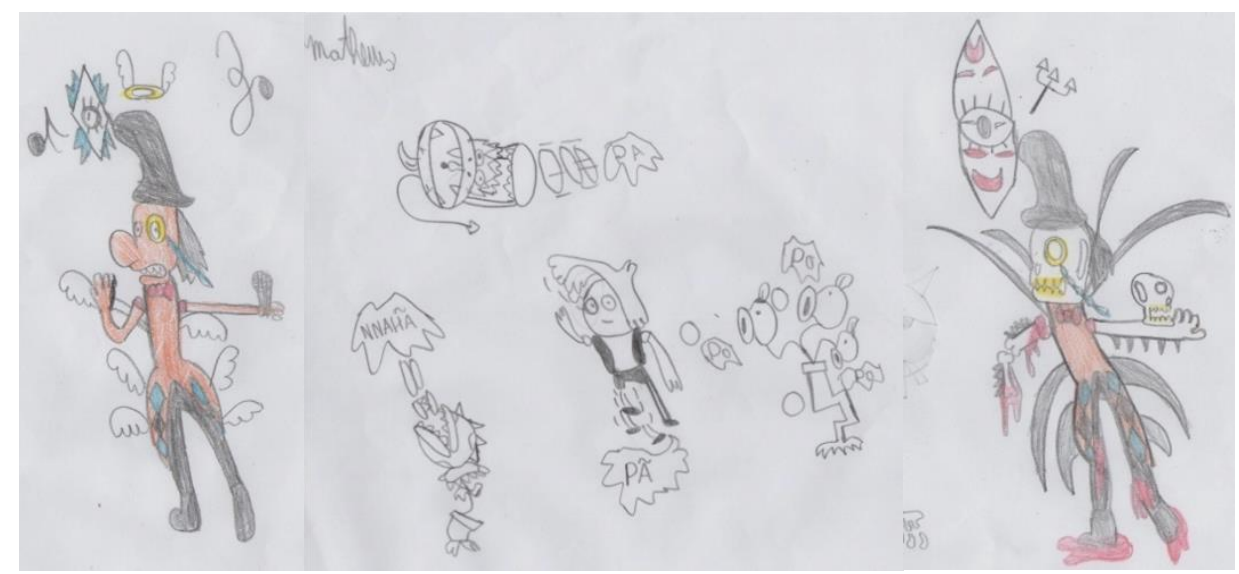

Fonte: Acervo pessoal.

Para Morin, "É enquanto representação da representação viva que o cinema", cujas as produções mais tarde seriam exibidas na televisão dentro dos grandes vínculos familiares, que "nos convida a refletir sobre o imaginário da realidade e a realidade do imaginário (p.14, 2014)". Percebe-se que tais produtos estabelecem uma 


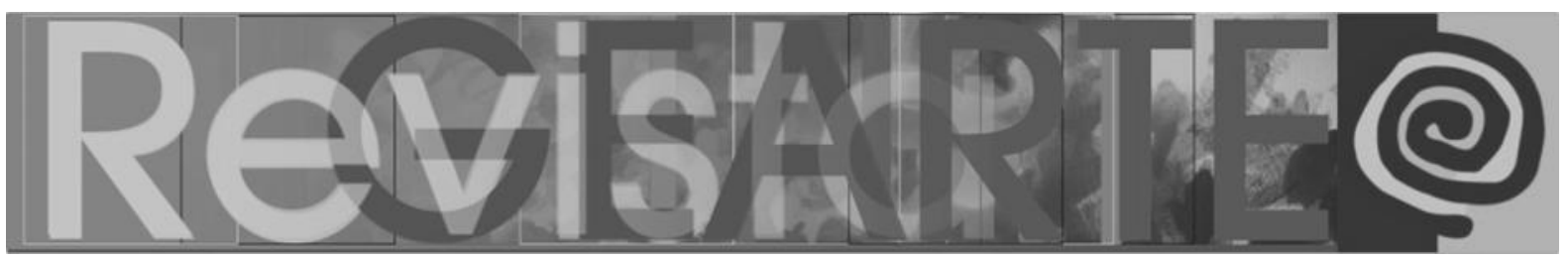

relação de permeabilidade com os mecanismos internos de apreensão de imagens ${ }^{2}$ visuais e auditivas reconfiguráveis dos consumidores, trazendo às diferentes vias sensoriais uma internalização consciente ou não, disposta em toda a configuração artística/audiovisual, além da ampliação do diálogo com outras imagens distantes do constructo social da realidade (ficção). Tais produções ao invadirem as televisões e adentrarem de forma nova mudando rotinas, pensamentos e até mesmo ações de seus espectadores, são vistas, deveras, "como um fenômeno de massa, de grande impacto na vida social moderna", que levadas a uma reflexão mais detida, compreende-se a "amplitude das experiências e a magnitude de suas repercussões" (MACHADO, 2000, p.10-11).

Nesse conglomerado de imagens, cada uma com suas particularidades, com suas vicissitudes pictóricas dentro das animações, para Pacheco (1995, p.47), o espectador infantil joga, brinca com seu imaginário, elabora suas penosas perdas, ao passo que é "inaceitável acreditar que durante tais jogos a criança seja passiva e acrítica. É inacreditável pensar que ela confunda ficç̧ão com realidade". Ela introjeta muitas das coisas que visualiza e também se desvencilha daquilo que não lhe apraz, visto que:

(...) o desenho animado possibilita que o imaginário infantil viva experiências que não poderiam ser vivenciadas no seu dia a dia real, estimulando sua capacidade imaginativa e de autoconhecimento (PRADO e MUNGIOLI, 2016, p.95).

A criança joga com o seu real e o irreal encontrado nas animações, e ao jogar brinca com as imagens, as manipula e as introjeta criativamente em seus desenhos.

Ao analisar perspicazmente os episódios das animações citadas, percebe-se que em todas as características notáveis dos personagens dos desenhos mais consumidos pelas crianças pesquisadas, têm neles em comum o pensamento

2 O termo Imagens visuais e sonoras é utilizado pelo neurocientista António Damásio em seus escritos e na entrevista acessada em Nov de 2018, disponível em: https://www.youtube.com/watch?v=n_g5vhzKaZQ. 


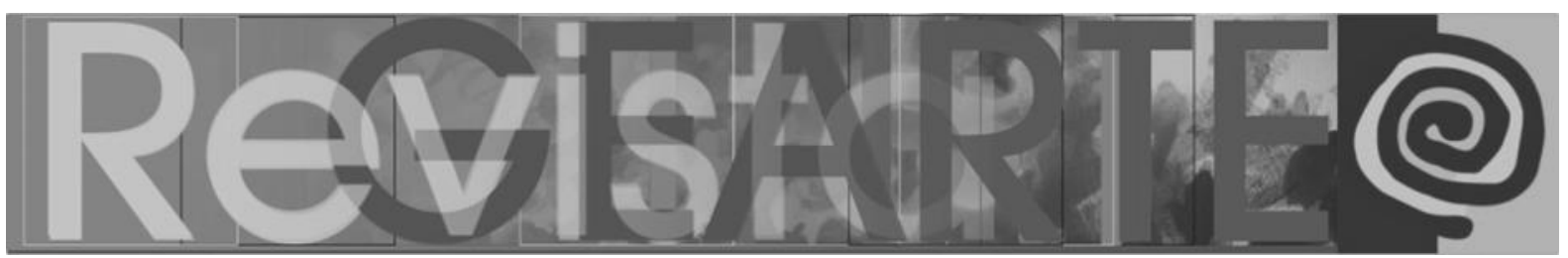

subversivo, que diverge de todas as convenções que os impõe a sociedade coetânea a eles. As ações divergentes são acordadas com as pesquisas de Guilford (1977) apud Wechsler (2002, p.37), que salientam a necessidade de "produção de respostas diferentes e alternativas" para o ato criativo, seja na produção de um determinado objeto ou na solução de problemas suscitados frente a algum acontecimento:

Eis o problema universal para todo cidadão: como adquirir a possibilidade de articular e organizar as informações sobre o mundo. Em verdade, para articulá-las e organizá-las, necessita-se de uma reforma de pensamento (MORIN, 2003, p.24).

A criança, ao se relacionar com o meio e consigo mesmo, ela a faz com ações que Ihes são naturais, subvertendo, articulando, se lançando ao mundo e organizando grande parcela das informações e conhecimentos com que tem contato, seja na escola, na rua, nos parques e/ou na própria televisão com que tem contato constantemente. Para ela, não existe uma égide padronizada, fixa, mas se comporta como um verdadeiro aventureiro, que se joga em busca de novas possibilidades, de novas organizações de pensamento, de saberes, de criação.

É verdade que são desenhos que foram criados para o público infanto-juvenil dentro do contexto da época, todavia não há como existir somente, olhando detidamente as produções animadas, o que Arlindo Machado (2000, p.23) diz ser uma modesta contribuição da televisão "de introduzir o público leigo e bárbaro dentro do campo da cultura secular e legítima" advinda de concepções rígidas e conservadoras de teóricos ao longo do tempo ao legitimarem, de forma alienados, sua qualidade. Além do que se costurou ou se configura dentro de tais produções, há ressonâncias muito mais duradouras do que apenas o conhecimento estático em si; há um instigar que desloca o espectador, o fã ávido por novas produções.

De forma holística, percebe-se que tanto as animações levantadas no decorrer dos escritos, quanto muitas outras que existem, podem propiciar "uma variedade muito grande de valores e oferecer propostas que sintetizem o maior número possível de "qualidades"' (MACHADO, 2000, p.25). Além disso, que nelas não se trabalha com 


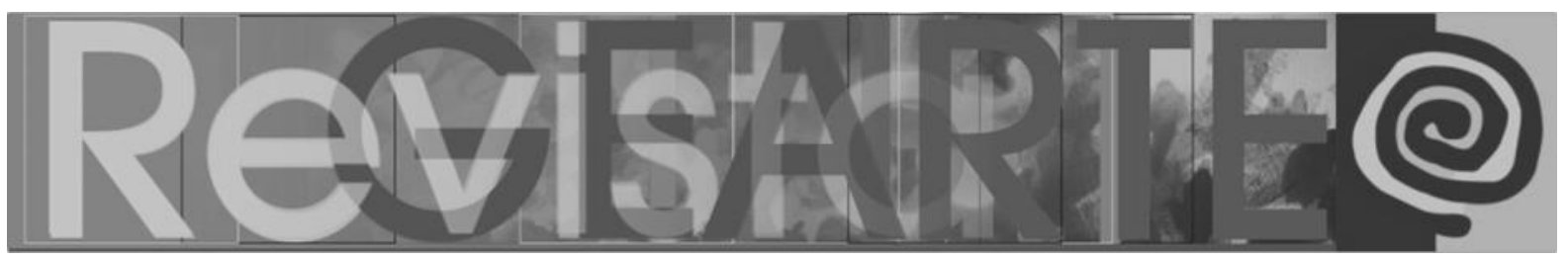

o foco em uma narrativa pobre, com um segmento muito obvio e previsível nos desenhos, contudo se opera com uma gama muito distinta de cânones que, talvez, engessam o despertar do imaginário pelo desenrolar da história e fatiga por serializações. São partes qualitativas de avultadas percepções, concepções, ações, culturas e tantos outros saberes que se congregam em um produto e que, consequentemente, ressoam aos consumidores, incitando-os a sentir, emocionar, refletir e agir dentro do meio social.

\section{Considerações finais}

O presente constructo textual mostra em linhas gerais que são inúmeras as possibilidades de introjeção de saberes que as produções audiovisuais podem propiciar aos fãs, uma vez que sons, imagens e narrativas são tecidas em um complexo que antes de tudo passou por uma ampla reflexão construtiva. Diante delas e a partir delas, evidencia-se em tal pesquisa que seus espectadores podem criar novas narrativas, nutrir seu imaginário de novas possibilidades de ações e divergir de aforismos configurados que possam estar em desacordo com seus pensamentos, como por exemplo, a mesma forma de se configurar um desenho ou uma narrativa para um determinado personagem ou lugar.

A partir do saber sobre o processo criativo, à luz da neuropsicologia, dos relatos de grandes criadores como o de Dragon Ball, Naruto e os autores de A lenda de Aang, percebe-se que há elementos em comum entre tais processos criativos e elementos imersos nas produções fílmicas e nos desenhos das próprias crianças que de fato consomem massivamente tais produções em televisões, computadores, tablets e celulares. Nota-se que tais produtos deveras podem propiciar e subsidiar o ato criativo, visto que a composição imagética cerebral decorrente das experiências externas quanto das relações com os produtos audiovisuais é semelhante.

Em todos os casos estudados não houve uma criação repentina, contudo um vasto e longo processo em contato com o meio externo, a internalização das experiências, a consolidação dessas memórias e o manusear de forma divergente as 


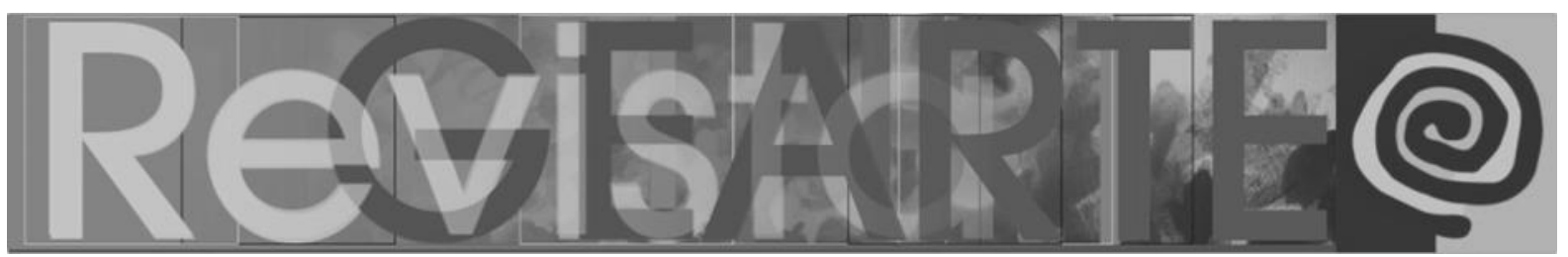

circundantes. Percebeu-se que a televisão ou os demais meios que difundem as animações aos seus consumidores deveras não os colocam em posição de meros receptáculos diante da profusão das mensagens com que estão tendo contato, mas atribui-Ihes a função de consumir e dialogar criticamente, ao tempo em que se nutrem das mais diferentes formas visuais e sonoras.

Partes cerebrais consolidam as memórias vivenciadas nas produções; mais adiante, com um conjunto de imagens, o ato imaginativo pode reorganizar, montar e desmontar o que bem achar, dando a cabo à criação. Não existe criação sem imaginação; tão depressa, acordado com os grandes teóricos supracitados, evidenciase que a assimilação dos constructos audiovisuais propiciados pela televisão, especificamente os desenhos animados, compõe o rol do constructo imagético necessário a tal ação. Entende-se melhor um ato criativo quando os olhares se lançam detidamente ao processo e todas as ressonâncias que propiciaram na conformação de tal produto, como as produções animadas televisivas, e, no momento que são difundidas todas essas estruturas imbuídas de informações e conhecimentos, elas se arraigam e compõem parte de todo o repertório visual dos fãs, que mais adiante, fazendo um resgate mnemônico de suas vivências televisivas, encontrar-se-ão diante de possibilidades maiores para também reconfigurar memórias.

Empreender uma pesquisa e se lançar aos acontecimentos circundantes a comunicação audiovisual, seu processo criativo e suas ressonâncias, é estar diante de um fenômeno cultural afeito à nossa própria época, que imersos em questionamentos e reflexões críticas, não somente encontramos coisas ruins, mas deveras produtos que dialogam com seus espectadores e os inserem dentro do arcabouço contemporâneo.

\section{Referências}

ADORNO, Theodor W; HORKHEIMER, Max. A indústria cultural: o esclarecimento como mistificação das massas. In: ADORNO, Theodor W; HORKHEIMER, Max. Dialética do esclarecimento. Tradução Antônio de Almeida. Rio de Janeiro: Jorge Zahar, 1985. 


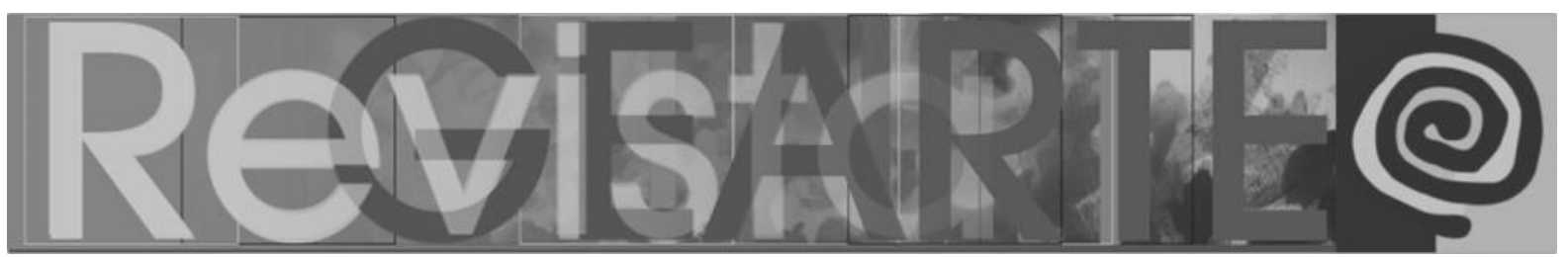

BACCEGA, Maria Aparecida. Televisão e educação: a escola e o Livro. Revista Comunicação e educação, do Departamento de Comunicações e Artes da Escola de Comunicações e Artes da Universidade de São Paulo, p. 7-14, maio/ago., 2002.

COSENSA, Ramon M. e Guerra, Leonor B. Neurociência e educação: como o cérebro aprende. Porto Alegre: Artmed, 2011.

DABUL, Lígia; PIRES, Bianca Salles. Set e ação: notas sobre processos criativos no cinema. Revista Poiesis, Niterói, v. 12, p. 77-88, nov., 2008.

DAMÀSIO, António R. $O$ erro de Descartes: emoção, razão e o cérebro humano; tradução de Dora Vicente, Georgina Segurado. 3‥ ed. São Paulo: Companhia das letras, 2012.

HOUZEL, Suzana Herculano. O cérebro nosso de cada dia: descobertas da neurociência sobre a vida cotidiana. $2^{\circ}$. Ed. Rio de Janeiro: Vieira e Lent, 2012.

IZQUIERDO, Iván. Memória. º. ed. Porto Alegre: Artmed, 2011.

LIMA JÚNIOR, Geraldo Coelho. Design de moda e neuroeducação: o desenvolvimento de uma metodologia de desenvolvimento projetual aplicado a pessoas com deficiência visual. Tese (doutorado em design) - Universidade Anhembi Morumbi, São Paulo, 2016.

MACHADO, Arlindo. A televisão levada a sério. São Paulo: Editora Senac, 2000.

MORIN, Edgard. Cultura de massas no século XX: O espírito do tempo-1. Neurose. Tradução de Maura Ribeiro Sardinha. 9‥ ed. Rio de Janeiro: Forense universitária, 1987.

MORIN, Edgard. O cinema ou o homem imaginário: ensaios de antropologia sociológica. Tradução de Luciano Loprete. São Paulo: Editora É Realizações, 2014.

MORIN, Edgard. A cabeça bem-feita: repensar a reforma, reformar o pensamento. Tradução de Eloá

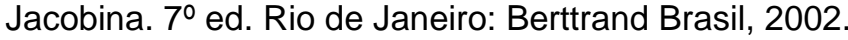

MORIN, Edgard. Da necessidade de um pensamento complexo. In: MARTINS, Francisco Menezes; SILVA, Juremir Machado (Orgs). Para navegar no século XXI: Tecnologias do imaginário e cibercultura. 3Ed. Porto Alegre: Sulina/EdiPUCRS, 2003.

MORIN, Edgard. Por uma reforma do pensamento. In: PENA-VEGA: ALMEIDA, Elimar Pinheiro (Orgs). O pensar complexo: Edgard Morin e a crise da modernidade. Rio de Janeiro: Garamond, 1999.

PACHECO, Elza Dias Pacheco (Org.). Televisão, criança e imaginário. São Paulo: Papirus Editora, 1998.

PACHECO, Elza Dias Pacheco. A linguagem televisiva e o imaginário infantil. Revista Comunicação e educação, do Departamento de Comunicações e Artes da Escola de Comunicações e Artes da Universidade de São Paulo, p. 43/48, jan./abr. ,1995.

PRADO, Laryssa Moreira; TRINTA, Aluizio R. Pensando a animação: meio é mensagem. Revista Movimento, São Paulo, n. 10, p.38-59, mar., 2018.

PRADO, Ana Lucia Penteado Brandão; MUNGIOLI, Maria Cristina Palma. Educomunicação e mediação escolar: um projeto educomunicativo para a relação criança, desenho animado e consumo. São Paulo; Revista Comunicação e educação, do Departamento de Comunicações e Artes da Escola de Comunicações e Artes da Universidade de São Paulo, n. 2, p. 87-96, jul./dez, 2016.

PILLAR, Analice Dutra. Contágios entre arte e mídia no ensino da Arte. Bahia; 19 Encontro da Associação Nacional de Pesquisadores em Artes Plásticas "entre territórios". Anpap. p. 1927 a 1940, 2010.

RAMACHANDRAN, Vilayanur S. O que o cérebro tem para contar: desvendando os mistérios da natureza humana. Tradução Maria Luiza X. de A. Borges. 1.ed. Rio de Janeiro: Zahar, 2014. 


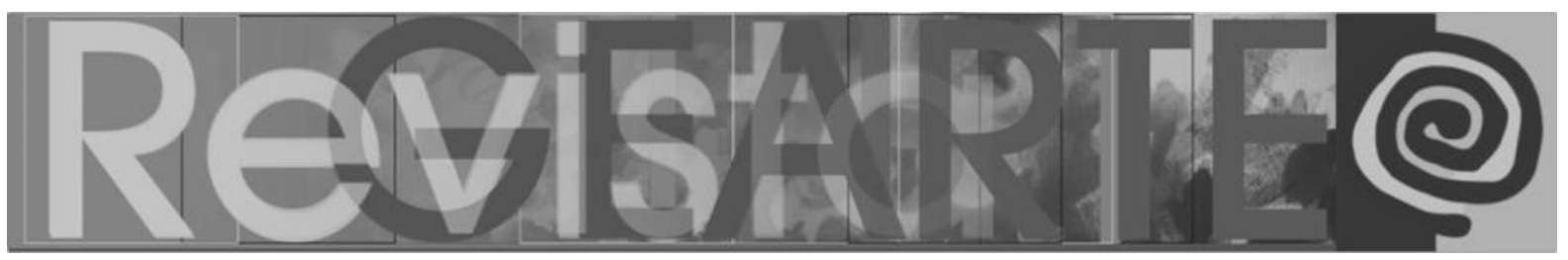

ROBERTS, Marcos Nadal; OLIVER, Albert Flexas. Bases biológicas de lacreatividad. El enfoque desde laneuroestética. In: ABRAHAM, Anna [Et al.]. Creatividad y neurociencia cognitiva. Madrid: Fundación Tomás Pascual y Pilar Gómez-Cuétara/ Instituto Tomás Pascual Sanz, 2012.

ROCHA, Marleide de Moura. A arte da animação japonesa: em busca dos recursos gerativos de sentidos. Recursos estéticos/efeitos estésicos. São Paulo: Pontifícia Universidade Católica de São Paulo/PUCSP. Dissertação de mestrado, 2008.

SILVA, André Luiz Souza. O Heroi na forma e no conteúdo: analise textual do mangá Dragon Ball e Dragon Ball Z. Dissertação (Mestrado em Comunicação e Cultura Contemporânea) - Universidade Federal da Bahia, Conselho Nacional de Desenvolvimento Científico e Tecnológico, 2005.

SILVA, Priscila Kalinke da. Educação, cultura escolar e mediação: em estudo o animê naruto. Maringá; Centro de Ciências Humanas, Letras e Artes da Universidade de Maringá. Dissertação de mestrado, 2012.

SINGER, Ben. Três: Modernidade, hiperestímulo e o início do sensacionalismo popular. In: CHARNEY et al (Org). O cinema e a invenção da vida moderna. Tradução: Regina Thompson. São Paulo: Cosac \& Naify Edições, 2001.

XIMENDES, Ellen. As bases neurocientíficas da criatividade: $O$ contributo da neurociência no estudo do comportamento criativo. Universidade de Lisboa: Faculdade de Belas Artes. Dissertação de mestrado, 2009.

WECHSLER, Solange Muglia (2002). Criatividade: descobrindo e encorajando. 3.ed. Campinas: livro.

\section{Isac dos Santos Pereira}

Mestrando em comunicação audiovisual pela Universidade Anhembi Morumbi. Possui graduação em Artes Visuais pela Faculdade Paulista de Artes (2013). Especialista em arte na educação: teoria e prática pela escola de comunicações e artes da Universidade de São Paulo. Especializando em Neurociências aplicada à educação. Tem experiência na área de Arte, com ênfase em Artes Visuais e música. É professor efetivo na rede municipal do ensino de São Paulo. Professor autodidata em Instrumentalização com ênfase em música erudita. Conhecimentos em órgão eletrônico, teclado e Violino.

E-mail: isacsantos02@hotmail.com

Currículo: http://lattes.cnpq.br/6351070667418404

Recebido em 28 de janeiro de 2019 Aceito em 10 de abril de 2019 